\title{
PENGEMBANGAN MODEL PEMBELAJARAN KARAKTER PADA PENDIDIKAN JASMANI MELALUI AKTIVITAS PERMAINAN PADA SISWASEKOLAH DASAR DI KABUPATEN MELAWI
}

\author{
Indria Susilawati ${ }^{1}$, Kartini ${ }^{2}$ \\ ${ }^{1,2}$ Dosen STKIP Melawi \\ Jl. RSUD Melawi km. 04 Kec. Nanga Pinoh Kab. Melawi Kalimantan Barat \\ Smile_indria@yahoo.com, kartini.lombok88@gmail.com
}

\begin{abstract}
This research aims to produce models penjasorkes learning through play activities for primary school student sare integrated with the character values of cooperation, responsibility and honesty. Research and developmentis done by adopting measures of research development: (1) the collection of informationin the field andan analysis ofthe information gathered, (2) developthe initial product (draft model), (3) expert validationandrevision, (4) small-scalefield trialsand revisions, (5) a largescale field trialsandrevisions, and (6) the manufacture ofthe finalproduct. Small-scale trials conducted on 5 th grade students 03 Melawi District of Kabupaten Melawi totaling 14 children and a large-scale trial conducted on 5 th grade students N 12 Melawi totaling 40 students. Data collection instruments used were: (1) interview, (2) scale value, (3) guidelines for the observation of the game, (4) the effectiveness of the guidance game observation, data analysis technique used is descriptive analysis of quantitative and qualitative descriptive analysis. The inference that learning through the game very well prepared to instill character values of cooperation, responsibility and honesty so that the model of learning through play activity is feasible to be used in learning.

Keywords: Learning Model Development, Character, Activity Games
\end{abstract}

\begin{abstract}
Abstrak: Penelitian ini bertujuan untuk menghasilkan model pembelajaran penjasorkes melalui aktivitas permainan bagi siswa sekolah dasar yang terintegrasi dengan nilai-nilai karakter kerjasama, tanggung jawab dan kejujuran.. Penelitian pengembangan ini dilakukan dengan mengadopsi langkah-langkah: (1) pengumpulan informasi di lapangan dan melakukan analisis terhadap informasi yang telah dikumpulkan, (2) mengembangkan produk awal, (3) validasi ahli dan revisi, (4) uji coba lapangan skala kecil dan revisi, (5) uji coba lapangan skala besar dan revisi, dan (6) pembuatan produk final. Uji coba skala kecil dilakukan terhadap siswa kelas 5 SD 03 Kabupaten Melawi yang berjumlah 25 anak dan uji coba skala besar dilakukan terhadap siswa kelas 5 SD N 12 Kabupaten Melawi yang berjumlah 85 siswa. Instrumen pengumpulan data yang digunakan yaitu:(1) pedoman wawancara, (2) skala nilai, (3) pedoman observasi permainan , (4) pedoman observasi keefektifan permainan, Teknik analisis data yang digunakan yaitu analisis deskriptif kuantitatif dan analisis deskriptif kualitatif. Simpulan bahwa pembelajaran melalui permainan yang disusun sangat baik untuk menanamkan nilai-nilai karakter kerjasama, tanggung jawab dan kejujuran sehingga model pembelajaran
\end{abstract}


melalui aktivitas permainan ini layak untuk digunakan dalam pembelajaran.

Kata Kunci: Pengembangan Model Pembelajaran, Karakter, Aktivitas Permainan.

endidikan dalam era global
menuntut berbagai perubahan pendidikan yang bersifat mendasar. Perubahan-perubahan tersebut di antaranya perubahan kehidupan dari masyarakat local ke masyarakat global. Sejak tahun 1998 UNESCO telah mengemukakan dua basis landasan, pertama: pendidikan harus diletakan pada empat pilar yaitu belajar mengetahui (learning to know). Belajar melakukan (learning to do), belajar hidup dalam kebersamaan learning to live together), dan belajar menjadi diri sendiri (learning to be): kedua, belajar seumur hidup (life long learning), (UNESCO, 1998 dalam Mulyasa). Pelaksanaan pendidikan di Indonesia diharapkan senantiasa mempertimbangkan dua basis landasan dari UNESCO tersebut.

Pendidikan karakter dapat dilakukan bersamaan dengan kegiatan belajar mengajar yang diintegrasikan dalam setiap mata pelajaran termasuk penjasorkes. Pendidikan jasmani tersebut tidak hanya merupakan sebuah gerak badan, tapi juga alat yang strategis untuk membina karakter. Menurut Doty
(2006: 1) People participate in sports for a variety of reasons health and fitness, stress management, socialization, relaxation, and others. One of the "other" reasons is character development. Di dalam penjasorkes banyak terkandung nilai-nilai karakter seperti sportivitas, kejujuran, keberanian, kerja keras, pengendalian diri, tanggung jawab, kerjasama, keadilan, dan kebijaksanaan, menghargai lawan dan sebagainya yang dapat diintegrasikan dalam aktivitas gerak dan dalam berbagai bentuk permainan. Dari pernyataan di atas jelas bahwa penjasorkes dapat menjadi ujung tombak dalam mengubah karakter bangsa Indonesia menjadi lebih kuat.

Periode usia sekolah dasar merupakan masa yang tepat untuk mengembangkan nilai-nilai karakter. Menurut Hasil observasi dan wawancara yang dilakukan oleh peneliti pada dua guru penjasorkes, Lorensius S.Pd, di SDN 27 Kabupaten Melawi dan Rahman,S.Pd. di SDN. 03 Sontas, yang ada di Entikong mengatakan, penjasorkes sangat berperan dalam membentuk kepribadian, sikap dan karakter anak, 
karena pembelajaran penjasorkes mengharuskan siswa untuk berinteraksi satu sama lain lewat aktivitas-aktivitas perminan. Anak akan terbiasa berinteraksi dengan teman-temannya dan memiliki rasa solidaritas di antara mereka yang sama-sama terlibat dalam suatu permainan atau tim yang sama.

Sebagian besar guru menyatakan sikap siswa dalam mengikuti pembelajaran dan kesehariannya di sekolah khususnya dari aspek kerjasama, tanggung jawab, dan kejujuran siswa, seiring berkembangnya arus informasi dan teknologi ternyata sangat berpengaruh terhadap karakter-karakter siswanya. Siswa cendrung bersifat individualis terkadang kurang mau perduli dengan lingkungan sekitar hal ini menurut guru dikarenakan anak terlalu sering berinteraksi dengan media-media sosial lewat internet seperti game online dan sebagainya khususnya siswa-siswa kelas atas.

Dalam hal kejujuran, siswa SD kelas atas sudah mulai mengerti untuk melakukan kecurangan-kecurangan ataupun menipu, hal ini tercermin dari beberapa sikap siswa yang terkadang berpura-pura sakit hanya karena ingin pulang padahal tidak sakit, sudah mulai timbul keinginan untuk mencontek dan sebagainya. Dalam aspek tanggung jawab guru sudah mulai berusaha menumbuhkan rasa tanggung jawab siswa sejak dini seperti pelaksanaan piket, memberikan tugas-tugas kepada siswa. Namun hal ini terkadang tidak berjalan sesuai yang diinginkan masih ada siswa yang tidak melakukan tugas tersebut seperti tidak melaksanankan piket kelas, datang ke sekolah terlambat dan tidak mengerjakan PR yang diberikan oleh guru melihat hal tersebut guru juga telah menyiapkan sanksisanksi bagi yang melanggar.

Dalam aspek kejujuran anak SD kelas atas khususnya kelas lima, sudah mulai timbul keinginan untuk bersikap tidak jujur baik itu pada saat bermain ataupun tidak mau mengakui kesalahan yang diperbuat dan justru kadang-kadang menuduh teman lainnya. Menurut beberapa guru penjasorkes, dalam aktivitas olahraga khususnya dalam pertandingan O2SN anak terkadang sudah mulai bermain curang dengan berpura-pura jatuh, agar lawan mendapat sangsi dari wasit. Menurut hasil observasi yang dilakukan peneliti pada saat pembelajaran, guru kurang memberi penekanan pada pengembangan nilainilai karakter khususnya dalam pembelajaran. Guru hanya memfokuskan pembelajaran pada gerak anak saja. Di 
dalam aktivitas bermain, guru kurang mau mengawasi peserta didik.

Dari pernyataan di atas jelas ada beberapa permasalahan khususnya dalam karakter anak yang seharusnya lebih diperhatikan dan ditekankan dalam sebuah proses pembelajaran penjasorkes karena pembelajaran bukan merupakan sebuah proses yang semata-mata menekankan pada aspek kognitif dan psikomotor yang hanya dinilai dengan angka-angka saja. Hal yang tidak kalah pentingnya pembelajaran tersebut harus mencakup aspek afektif dan perilaku baik. Agar natinya penerus bangsa ini tidak hanya cerdas secara intelektual dan kinestetik tapi juga mempunyai moral dan tingkah laku yang baik sesuai dengan nilai-nilai luhur Pancasila, pendidikan jasmani merupakan alat yang dirasa tepat dalam mengembangkan aspek-aspek karakter dalam diri anak, karena penjasorkes merupakan proses pembelajaran yang mampu mencakup ketiga aspek tersebut secara langsung.

Oleh karena itu peneliti yakin, lewat permainan aktivitas jasmani upaya untuk pembelajaran karakter anak usia sekolah dasar khususnya kelas atas akan dapat dilakukan, sehingga peneliti tertarik untuk membuat model-model permainan aktivitas jasmani yang di dalamnya terkandung nilai-nilai karakter untuk anak sekolah dasar. Peneliti berasumsi bahwa dengan membuatmodel permainan, bola bekap, berburu rusa, voli lempar tangkap, dan bola keranjang tersebut anak tidak hanya sebatas mengetahui nilai-nilai karakter yang baik, namun mau melakukan tindakan tersebut dan nantinya diharapkan menjadi habituasi (kebiasaan) dalam diri anak, sehingga diharapkan penerus bangsa ini nantinya akan memiliki karakter yang kuat sesuai dengan nilainilai luhur yang terkandung di dalam Pancasila.

\section{METODE PENELITIAN}

Penelitian ini merupakan penelitian (research based development). yang bersifat deskritif, Prosedur penelitian dalam penelitian ini direncanakan menggunakan langkah-langkah penelitian pengembangan Borg dan Gall (1983:775) mengatakan dalam melakukan penelitian pengembangan terhadap terdapat langkah yang harus ditempuh sebagai berikut:

pengumpulan hasil riset,

Perencanaan, (3) mengembangkan produk awal, (4) uji coba awal, (5) revisi untuk menyusun produk utama, (6) uji coba lapangan utama, (7) revisi untuk menyusun produk operasional, (8) uji coba produk operasional, (9) revisi produk final, dan (10) diseminasi dan 
implementasi produk hasil pengembangan. Kemudian langkahlangkah tersebut diadaptasi menjadi 6 tahapan sebagai berikut: (1) Studi pendahuluan dengan melakukan pengumpulan informasi dan analisis terhadap informasi yang telah dikumpulkan, (2) mengembangkan produk awal, (3) validasi ahli dan revisi, (4) ujicoba lapangan dengan skala kecil dan revisi produk, (5) ujicoba skala besar dan revisi produk (6) Produk akhir.

Uji coba dilakukan dengan tujuan untuk menyempurnakan model permainan dengan mempraktekkannya secara langsung di lapangan. Dalam penelitian ini, uji coba produk/draf model pembelajaran dilakukan sebanyak dua kali, yaitu uji coba skala kecil dan uji coba skala besar. Uji coba produk skala kecil dilakukan terhadap siswa kelas $\mathrm{V}$ SD 03 Sontas, yang berjumlah 25 orang, sementara uji coba skala besar dilakukan terhadap siswa kelas V SD 12 Entikong, yang berjumlah 85 siswa. Kemudian dalam tahap uji coba dilapangan peranperan dari para pakar serta guru penjasorkes adalah untuk mengobservasi kelayakan draf model yang telah disusun dengan kenyataan di lapangan kemudian setelah ujicoba skala luas maka akan menghasilkan sebuah model yang benarbenar valid.
Instrumen pengumpulan data yang dikumpulkan dari penelitian ini berupa data kualitatif dan kuantitatif. Data kualitiatif diperoleh dari: (a) hasil wawancara dengan guru SD; Wawancara digunakan sebagai teknik pengumpulan data apabila peneliti ingin melakukan studi pendahuluan untuk menemukan permasalahan yang harus diteliti, dan juga apa bila peneliti ingin mengetahui hal-hal dari responden yang lebih mendalam dan jumlah respondennya sedikit/kecil (Sugiyono, 2007:138).

Teknik pengumpulan data yang digunakan yaitu teknik komunikasi langsung dengan menggunakan instrumen wawancara sebagai alat pengumpul data. Definisi dari teknik komunikasi langsung adalah mekanisme pengumpulan data yang dilakukan melalui kontak atau hubungan pribadi dalam bentuk tatap muka (faceto face relationship) antara pengumpul data dengan responden, sedangkan wawancara adalah alat pengumpul data berupa tanya jawab antara pihak pencari informasi (interviewer) dengan sumber informasi (responden/interviewee) yang berlangsung secara lisan (Nawawi 2006, : 98).Untuk merekam hasil wawancara digunakan handphone. data saran dan masukan perbaikan model permainan dari ahli materi sertaguru. Data 
kuantitatif, penilaian ahli materi terhadap permainan, penilaian ahli materi terhadap karakter yang muncul pada setiap permainan; (c) penilaian guru terhadap siswa.

Instrumen pengumpulan data kedua yang digunakan yaitu skala nilai. Skala nilai ini digunakan untuk menilai kelayakan model permainan yang dikembangkan sebelum pelaksanaan ujicoba skala kecil. Setelah para ahli menilai bahwa model permainan sudah sesuai dengan unsur-unsur dalam skala nilai, model permainan baru dapat diujicobakan dalam uji coba skala kecil. Dalam skala nilai, variabel atau tujuan penelitian diklasifikasikan secara rinci menjadi gejala-gejala dengan unsurunsurnya. Klasifikasi tersebut disusun ke bawah, sedangkan kesamping dicantumkan kategori sesuai dengan maksud/tujuan penelitian, antara lain berupa urutan kualitas data yang dikumpulkan. Kategori yang dimaksud dalam skala penilaian ini adalah kategori berskala dua, yaitu sesuai dan tidak sesuai. Cara penggunaan skala nilai yaitu, bila mana muncul gejala atau unsur-unsur seperti yang terdapat dalam klasifikasi data, para pakar dan guru memberikan tanda cek $(\sqrt{ })$ pada kolom kategori yang sesuai. Apabila gejala atau unsur-unsur seperti yang terdapat dalam klasifikasi data dinyatakan sesuai maka nilainya satu (1), apa bila dinyatakan tidak sesuai maka nilainya nol (0).

Teknik pengumpulan data ketiga yang digunakan yaitu teknik observasi tidak langsung dengan instrumen observasi berupa daftar cek (check list) dan peralatan mekanik. Observasi sebagai teknik pengumpulan data mempunyai ciri yang spesifik bila dibandingkan dengan teknik yang lain, yaitu wawancara dan kuesioner. Teknik pengumpulan data dengan observasi digunakan bila penelitian berkenaan dengan perilaku manusia, proses kerja, gejala-gejala alam dan bila responden yang di amati terlalu besar (Sugiyono, 2007:145). Teknik observasi tidak langsung merupakan cara mengumpulkan data yang dilakukan melalui pengamatan dan pencatatan gejala-gejala yang tampak pada objek penelitian yang dilaksanakan setelah peristiwa atau situasi atau keadaannya terjadi.

Instrumen penilaian anak adalah format penilaian yang digunakan guru untuk menilai kinerja anak saat melaksanakan permainan-permainan yang dikembangkan. Dengan format penilaianini akan memudahkan guru dalam mengevaluasi penampilan anak dan ketercapaian indikator yang diharapkan dari tiap permainan. Terdapat 
empat format penilaian untuk empat permainan yang dikembangkan. Format penilaian untuk masing-masing permainan berbeda karena indikator tujuan permainan yang berbeda-beda dalam tiap permainan. Kisi-kisi format penilaian anak sama dengan kisi-kisi instrument untuk mengobservasi keefektifan model permainan.

\section{HASIL DAN PEMBAHASAN}

Berdasarkan analisis data yang telah dilakukan model pembelajaran karakter pada pendidikan jasmani melalui aktifitas permainan bola bekap, berburu rusa, voli lempar tangkap dan, bola keranjang yang sudah dikemas secara menarik dengan peraturan permainan dan alat-alat yang digunakan disesuaikan dengan kebutuhan siswa sekolah dasar. Pengembangan model pembelajaran karakter bola bekap, voli lempar tangkap, berburu rusa, dan bola keranjang aman dimainkan dan alat-alat yang digunakan relative murah dan mudah didapat. Pengembangan model pembelajaran karakter dapat membantu guru penjasorkes dalam proses pembelajaran karakter di sekolah dasar untuk pembelajaran karakter kerjasama, tanggung jawab, dan kejujuran untuk siswa sekolah dasar kelas V ( lima).

Berdasarkan langkah-langkah penelitian pengembangan model pembelajaran permainan dalam membentuk karakter kerjasama, tanggung jawab dan kejujuran meliputi, 1) observasi terhadap model permainan, 2) data penilaian terhadap karakter yang muncul dalam permainan. Berdasarkan penilaian uji coba skala besar dari guru dan ahli terhadap model permainan bola bekap terlihat bahwa yang didapat menunjukkan total nilai yaitu 240 dengan total nilai rata-rata 16 . Data skala besar ahli terhadap karakter uji coba skala besar dari para ahli terhadap karakter yang muncul pada model permainan bola bekap, hasil yang didapat telah menunjukkan nilai maksimal yaitu 100\% yang berada didalam katagori sangat baik.

Tabel 1. Data Skala Besar Ahli
dan guru terhadap Permainan " Bola
Bekap"
Ahli Materi \begin{tabular}{ccc} 
Total & Rata- \\
& Nilai & Rata \\
\hline Ahli 1 & 60 & 4 \\
Ahli 2 & 60 & 4 \\
Guru 1 & 60 & 4 \\
Guru 2 & 60 & 4 \\
\hline Berdasarkan & penilaian ahli dan
\end{tabular}
guru terhadap model permainan berburu rusa hasil yang didapat menunjukkan total nilai yaitu 240 dengan total nilai rata-rata 16. Data skala besar ahli terhadap karakter uji coba skala besar dari para ahli terhadap karakter yang muncul pada model permainan berburu rusa, hasil yang didapat telah 
menunjukkan nilai maksimal yaitu $100 \%$ yang berada didalam katagori sangat baik.

Tabel 2. Data Skala Besar Ahli dan guru terhadap Permainan "Berburu Rusa",

\begin{tabular}{ccc}
\hline Ahli Materi & Total Nilai & Rata-Rata \\
\hline Ahli 1 & $\mathbf{6 0}$ & $\mathbf{4}$ \\
Ahli 2 & $\mathbf{5 8}$ & $\mathbf{3 , 9}$ \\
Guru 1 & $\mathbf{5 6}$ & $\mathbf{3 . 7}$ \\
Guru 2 & $\mathbf{6 0}$ & $\mathbf{4}$ \\
\hline
\end{tabular}

Berdasarkan penilaian dari para ahli terhadap karakter yang muncul pada model permainan memasukkan bola ke kranjang. Terlihat bahwa hasil yang didapat menunjukkan total nilai yaitu 234 dengan total nilai rata-rata 11,8 . Data skala besar ahli terhadap karakter uji coba skala besar dari para ahli terhadap karakter yang muncul pada model permainanmemasukan bola kekranjang, hasil yang didapat telah menunjukkan nilai maksimal yaitu $100 \%$ yang berada didalam katagori sangat baik.

Tabel 3. Data Skala Besar Ahli dan guru terhadap Permainan "Bola Keranjang",

\begin{tabular}{ccc}
\hline Ahli Materi & Total Nilai & Rata-Rata \\
\hline Ahli 1 & $\mathbf{6 0}$ & $\mathbf{4}$ \\
Ahli 2 & $\mathbf{6 0}$ & $\mathbf{4}$ \\
Guru 1 & $\mathbf{6 0}$ & $\mathbf{4}$ \\
Guru 2 & $\mathbf{6 0}$ & $\mathbf{4}$ \\
\hline Berdasarkan & penilaian & dari para
\end{tabular}

ahli terhadap karakter yang muncul pada model permainan voli lempar tangkap. Terlihat bahwa hasil yang didapat menunjukkan total nilai yaitu 237 dengan total nilai rata-rata 15,8 . Data skala besar ahli terhadap karakter uji coba skala besar dari para ahli terhadap karakter yang muncul pada model permainan voli lempar tangkap, hasil yang didapat telah menunjukkan nilai maksimal yaitu 100\% yang berada didalam katagori sangat baik. Berdasarkan hasil dari uraian di atas peneliti berkesimpulan bahwa model pembelajaran karakter pada pendidikan jasmani melalui aktivitas permainan dapat dijadikan salah satu bahan ajar untuk pembelajaran penjasorkes.

Tabel 4. Data Skala Besar Ahli dan guru terhadap Permainan "Voli Lempar Tangkap”,

\begin{tabular}{ccc}
\hline Ahli Materi & Total Nilai & Rata-Rata \\
\hline Ahli 1 & $\mathbf{6 0}$ & $\mathbf{4}$ \\
Ahli 2 & $\mathbf{5 7}$ & $\mathbf{3 . 8}$ \\
Guru 1 & $\mathbf{6 0}$ & $\mathbf{4}$ \\
Guru 2 & $\mathbf{6 0}$ & $\mathbf{4}$ \\
\hline
\end{tabular}

\section{Permainan Berburu Rusa}

Permainan ini bertujuan untuk mengembangkan aspek biomotor dan karakter siswa. Adapun aspek biomotor yang berpengaruh yaitu: (1) kekuatan, (2) kelincahan dan (3) kemampuan koordinasi siswa dalam melempar dan menangkap bola. Selain aspek biomotor permainan ini juga memfokuskan kepada pengembangan karakter siswa khususnya dalam hal kejujuran antara lain: (1) mau mentaati peraturan permainan, (2) tidak bermain curang, dan (3) mau mengakui kesalahan apabila melanggar peraturan. Peralatan: Tali atau kapur bubuk untuk 
membuat lapangan dengan ukuran Panjang $10 \mathrm{M}$ dan lebar $10 \mathrm{M}$, bola modifikasi yang terbuat dari bahan karet dengan ukuran 3 dan berdiameter 16-20.

Aturan keselamatan pada permainan ini bola yang digunakan dari bahan yang lunak sehingga siswa tdak merasa sakit apabila bola terkena anggota tubuh mereka. Catatan lapangan yang digunakan bisa diperbesar atau pun diperkecil disesuaikan dengan jumlah siswa, serta bola yang digunakan bisa lebih dari satu sesuai dengan jumlah siswa yang bermain.

Cara bermain, siswa dibagi menjadi dua tim yaitu tim yang menjadi pemburu yang berada diluar lapangan dan yang menjadi rusa yang berada di dalam lapangan. Masing-masing berjumlah 7-10 siswa. Permainan dilakukan dengan cara lempar tangkap serta menembak bola hingga mengenai tim yang berperan sebagai rusa yang berada di dalam lapangan. Bola yang digunakan pada permainan ini adalah bola modifikasi yang terbuat dari bahan karet. Tim yang berada di dalam lapangan berusaha mengindari lemparan bola dari tim pemburu. Permainan dibuat dengan dua sesi yaitu dengan cara bergantian peran antara tim yang menjadi pemburu dan yang menjadi kancil. Setiap sesi permainan dibatasi waktu 20 menit.
Pemenang dalam permainan ini adalah kelompok yang paling sedikit terkena lemparan dalam waktu 10 menit.

\section{Permainan Bola Bekap}

Permainan ini bertujuan untuk mengembangkan aspek biomotor dan karakter siswa. Adapun aspek biomotor yang berpengaruh yaitu: (1) kekuatan, (2) kelincahan dan (3) kemampuan koordinasi siswa dalam melempar dan menangkap bola. Selain aspek biomotor permainan ini juga memfokuskan kepada pengembangan karakter siswa khususnya dalam hal kejujuran antara lain: (1) mau mentaati peraturan permainan, (2) tidak bermain curang, dan (3) mau mengakui kesalahan apabila melanggar peraturan.

Peralatan lapangan modifikasi dengan ukuran panjang $10 \mathrm{M}$ dan Lebar $5 \mathrm{M}, 1$ buah bola modifikasi yang terbuat dari karet dengan ukuran 3 diameter 16-20 cm. Aturan keselamatan pada permainan ini bola yang digunakan dari bahan yang lunak sehingga siswa tdak merasa sakit apabila bola terkena anggota tubuh mereka. Catatan lapangan yang digunakan bisa diperbesar ataupun diperkecil disesuaikan dengan jumlah siswa, serta bola yang digunkan bisa lebih dari satu sesuai dengan jumlah siswa yang bermain.

Cara bermain, anak dibagi menjadi dua kelompok yaitu kelompok A dan B 
yang masing-masing kelompok berjumlah 7-10 orang. Permainan dilakukan dalam waktu 10-15 menit.

Pelaksanaan awal permainan setiap tim memposisikan dirinya digaris belakang lapangan masing-masing dan berjajar. Bola diletakan di garis tengan lapangan. Pada saat guru meniupkan peluit arti tanda permainan dimulai siswa masing-masing kelompok A dan B berlari kegaris tengah untuk berebut mendapatkan bola yang ada digaris tengah. Siswa yang mendapat bola kemudian mengoper bola keteman kelompoknya dan berusaha melempar bola tersebut hingga mengenai kaki kelompok lawan. Pemain yang mendapat bola tidak diperbolehkan lari atau pun jalan. Jadi bola hanya boleh di oper ke teman atau dilempar ke tim lawan.

Kelompok yang menjadi sasaran lemparan berlari menghindari lemparan tersebut apabila ada siswa yang terkena lemparan. Siswa tersebut langsung memposisikan dirinya di luar garis paling belakang pada posisi lawan. Tujuannya untuk membantu kelompok nya menembak bola ke tim lawan. Apabila pada saat melempar bola tersebut tidak mengenai sasaran dan bola berada diposisi lawan maka bola tersebut akan dikuasai oleh lawan. Tim yang dinyatakan menang dalam permainan ini adalah tim yang paling banyak terkena lemparan atau yang paling banyak berada diluar lapangan. Namun inti dari permainan ini tidak hanya bagaimana setiap tim tersebut mampu melempar bola mengenai sasaran yang ditentukan. Melainkan unsur-unsur nilai-nilai kejujuran yang juga dipertimbangkan dalam permainan ini, yaitu bagaimana siswa mampu mentaati peraturan yang ada, dan mau mengakui apabila telah melanggar peraturan tersebut.

\section{Permainan Bola Keranjang}

Permainan ini bertujuan untuk mengembangkan aspek biomotor dan karakter siswa. Adapun aspek biomotor yang berpengaruh yaitu: (1) kekuatan, (2) kemampuan koordinasi siswa dalam melempar dan menangkap bola, (3) kecepatan dalam mengejar dan menangkap bola. Selain aspek biomotor permainan ini juga memfokuskan kepada pengembangan karakter siswa khususnya dalam hal tanggung jawab antara lain: (1) bermain dengan sungguh-sungguh, (2) berusaha memasukan bola ke dalam keranjang lawan, dan (3) menjaga keranjang sendiri agar lawan tidak dapat memasukan bola. Peralatan Tali atau kapur bubuk untuk membuat lapangan dengan ukuran lapangan panjang $16 \mathrm{M}$ dan lebar $10 \mathrm{M}$, bola modifikasi yang 
terbuat dari bahan karet ukuran 3 dengan diameter 16-20 cm dan 2 buah keranjang.

Peraturan peralatan lapangan dengan kapur bubuk atau tali rafia dengan ukuran lapangan berbentuk persegi panjang dengan panjang $16 \mathrm{M}$ dan lebar $10 \mathrm{M}$ kemudian menyiapkan 2 buah keranjang, dan1 buah bola modifikasi dengan ukuran 3 diameter 16$20 \mathrm{~cm}$. Aturan Keselamatan Garis lapangan yang digunakan dibuat dengan kapur bubuk, pada saat bola sudah ditangkap lawan tidak diperkenankan merebut bola tersebut, agar tidak terjadi benturan sesama pemain.

Catatan lapangan yang digunakan bisa diperbesar ataupun diperkecil disesuaikan dengan jumlah siswa, target yang digunakan dapat berupa keranjang dengan berbagai macam ukuran. Cara bermain siswa dibagi dalam dua tim masing-masing berjumlah 6-7 siswa dan setiap tim mempunyai keranjang yang harus dijaga agar lawan tidak dapat memasukan bola kekeranjang tersebut. Permainan dilakukan dengan cara lempar tangkap dan setiap tim berusaha melempar bola dan memasukannya kedalam keranjang lawan. Bola yang digunakan adalah bola modifikasi yang terbuat dari karet. Permainan dilakukan dalam waktu 10-15 menit. Tim yang dinyatakan sebagai pemenang adalah tim yang paling banyak memasukan bola ke dalam keranjang lawan. Permainan ini memiliki nilai karakter yang akan dikembangkan yaitu nilai tanggung jawab. Di dalam permainan ini akan terlihat dan melatih tanggung jawab siswa terhadap timnya maupun dirinya sendiri dalam berusaha mempertahankan daerahnya agar tidak terjadi gol maupun melakukan serangan ke daerah lawan.

\section{Permainan Voli Lempar Tangkap}

Permainan ini bertujuan untuk mengembangkan aspek biomotor dan karakter siswa. Adapun aspek biomotor yang berpengaruh yaitu: (1) kekuatan, dan (2) kemampuan koordinasi siswa dalam melempar dan menangkap bola. Selain aspek biomotor permainan ini juga memfokuskan kepada pengembangan karakter siswa khususnya dalam hal kerjasama antara lain: (1) siswa mau bekerjasa sama dalam mengoper bola, (2) siswa tidak memilih teman tertentu dalam mengoper bola, (3) siswa tidak bertengkar dalam melakukan permainan.

Peralatan tali atau kapur bubuk untuk membuat lapangan dengan ukuran panjang $12 \mathrm{M}$ dan lebar $6 \mathrm{M}$, bola modifikasi dengan ukuran 3 diameter 16$20 \mathrm{~cm}$ yang terbuat dari bahan karet, net atau tali untuk membatasi lapangan dengan tinggi $2 \mathrm{M}$. Aturan keselamatan 
Garis lapangan tidak dibuat dengan tali melainkan dibuat dengan kapur bubuk, agar siswa pada saat bermain tidak jatuh pada saat berlari. Catatan lapangan yang digunakan bisa diperbesar ataupun diperkecil disesuaikan dengan jumlah siswa yang bermain.

Cara bermain, siswa dibagi dalam dua tim yang dipisahkan oleh tali sebagai net atau pembatas. Permainan dilakukan semacam permainan bola voli tetapi dengan cara lempar tangkap. Peserta permainan terdiri dari 7-8 siswa dalam setiap tim.

Permainan dilakukan dalam waktu 10 menit, permainan pertama dilakukan dengan servis yaitu dengan melempar bola kedaerah lawan kemudian bola ditangkap oleh lawan dan dioper sebanyak 4 kali ke rekan tim, tujuannya adalah agar terlihat aspek kerjasama dalam bermain diantara peserta didik tersebut, kemudian bola masih boleh ditangkap apabila jatuh dengan satu kali pantulan, bola dioper tidak kepada orang yang sama, setelah bola dioper sebanyak 4 kali kemudian bola dilempar ke daerah lawan. Pada saat bola sampai ke daerah lawan hal yang sama dilakukan oleh tim yang memegang bola yaitu dengan mengoper bola sebanyak 4 kali. Setiap tim berusaha melempar bola ke daerah lawan dan membuat tim lawan sulit mengkapnya. Poin di dapat apabila: Bola tidak dipasing 4 kali dalam setiap tim, Pada saat pasing bola, ada pemain yang melakukan double pasing atau 2 kali pasing orang yang sama, apabila lawan tidak mampu menangkap bola dan lebih dari satu pantulan, apabila bola jatuh dilapangan yang kosong dan apabila bola tidak melewati net atau tali atau bola keluar dari lapangan permainan. Tim yang dinyatakan sebagai pemenang adalah tim yang paling banyak memiliki poin.

\section{SIMPULAN}

Dari penelitian yang telah dilakukan dapat disimpulkan bahwa hasil penilaian para ahli dan guru sebagai praktisi di lapangan menyatakan bahwa model pembelajaran permainan yang disusun sangat baik dan layak digunakan dalam pembelajaran untuk mengembangkan nilai-nilai karakter, kerjasama, tanggung jawab dan kejujuran. Adapun aktivitas permainan yang dikembangkan antara lain: (1) permainan berburu rusa, (2) Permainan bola bekap, (3) permainan memasukan bola ke keranjang dan, (4) permainan voli lempar tangkap.

Produk dari penelitian pengembangan ini yaitu buku panduan dan video pengembangan model pembelajaran penjasorkes melalui 
aktivitas permainan untuk pembelajaran karakter yang berjudul "Pengembangan model pembelajaran karakter pada permainan" dengan dikembangkannya model permainan tersebut diharapkan dapat menjadi alternatif bagi guru dalam memberikan pembelajaran ke siswa untuk menanamkan nilai-nilai karakter positif khususnya, kerjasama, tanggung jawab dan kejujuran.

\section{DAFTAR PUSTAKA}

Borg, Wjr R. \& Gall, J. P. 1983. Educational research (an Introducition). 4 th ed. New York: Longman.

Doty, J. 2006. "Sports Build Character". Journal of College and Character Volume VII, No. 3, April 2006.
Milson, A. J. 2002. "Developing A Comprehensive Approach To Character Education In The Social Studies". Journal proguest the social studies, 101,93,3.

Munir, A. 2010. Pendidikan Karakter: Membangun Karakter Anak Sejak dari Rumah. Yogyakarta: PT Pustaka Insan Madani

Nawawi, H. \& Hadari, M. 2006. Instrumen Penelitian Bidang Sosial. Yogyakarta: Gadjah Mada University Press.

Samani, M. 2011. Konsep dan Model Pendidikan Karakter. Bandung: PT Remaja Rosdakarya.

Sugiyono. 2007. Metode penelitian kuantitatif, kualitatif dan $R \& D$. Bandung: Alfabeta Bandung. 